\title{
MISE EN SCÈNE FILM NYAI KARYA GARIN NUGROHO
}

\author{
Surya Farid Sathotho, Philipus Nugroho Hari Wibowo, Nur Annisa Savini \\ Jurusan Teater FSP ISI Yogyakarta \\ suryafarid@isi.ac.id
}

\begin{abstract}
Abstrak: Nyai (2016) merupakan sebuah film karya Garin Nugroho yang dibuat hanya dengan menggunakan satu kamera dan pengambilan gambarnya secara terus menerus tanpa henti (long take) untuk satu film secara penuh. Konsekuensi dari teknik tersebut menyebabkan Film Nyai tak ubahya seperti pementasan teater di atas panggung. Karya ini terinspirasi oleh beberapa karya sastra sekaligus.

Untuk melakukan analisis terhadap Film Nyai, menggunakan konsep yang dikenal awal mulanya sebagai sebuah konsep pemanggungan di atas panggung teater dan pada perkembangan selanjutnya dikenal juga dalam dunia sinematografi. Pemahaman mengenai mise en scène ini sangat penting untuk pijakan melakukan analisis terhadap unsur-unsur yang ada dalam Film Nyai.

Nyai merupakan film dengan idiom pertunjukan teater yang sangat kental. Blocking, Setting, Make Up benar-benar seperti pertunjukan teater di atas panggung. Sedangkan pergerakan, sudut pengambilan dan pemilihan lensa kamera dibuat semirip mungkin dengan pandangan manusia.
\end{abstract}

\section{kata kunci: mise en scène, film nyai, garin nugroho}

\begin{abstract}
Nyai (2016) is a film by Garin Nugroho using only single camera and using long take technique for the whole film. As a consequence of this technique, Nyai Film is similar to the staging of theatre performance. This work is inspired by several literary works at once. To conduct an analysis of Nyai, it uses a concept that was known in the beginning as a staging concept on the theater stage and later known in the world of cinematography. This understanding of mise en scène is very important for the basis of analyzing the elements in Nyai.

Nyai is a film with a very strong theatrical idiom. Blocking, Setting, Make Up are very similar compared to theatre performances on stage. Meanwhile, the movement, angle of camera and selection of the camera lens are made as close as possible to human view.
\end{abstract}

\section{keywords: mise en scène, nyai, garin nugroho}

\section{Pendahuluan}

Film Nyai disutradarai oleh Garin Nugroho yang dibuat pada tahun 2016. Film ini tayang perdana di Busan International Film Festival pada Oktober 2016, kemudian dilanjutkan di Torino International Film Festival 2016, Singapore International Film
Festival 2016, Rotterdam International Film Festival 2017, dan Goteborg International Film Festival 2017 (Riantrisnanto, 2018).

Garin mengatakan, film garapannya tidak akan beredar di bioskop-bioskop reguler. Namun, sineas asal Yogyakarta itu menyebut Nyai layak untuk ditonton sebagai pengantar sejarah film Indonesia. "Maka 
kami akan memperbanyak pemutaran dengan komunitas-komunitas dan melengkapinya dengan rangkaian master class." (JPNN.COM, 2018)

Film Nyai terinspirasi oleh beberapa karya sastra sekaligus, yaitu Nyai Isah (1940) karya F. Wiggers; Seitang Koening (1960) karya R.M Tirto Adhisoerjo; Boenga Roos dari Tjikembang (1927) karya Kwee Tek Hoay; Nyai Dasima (1960) karya S.M Ardan dan Bumi Manusia (1980) karya Pramoedya Ananta Toer. Karya-karya tersebut bukanlah karya yang remeh temeh mengingat ada nama-nama penulis besar didalamnya. Film Nyai bercerita tentang pergundikan, harga diri seorang wanita pribumi yang jatuh karena kawin dengan seorang Belanda.

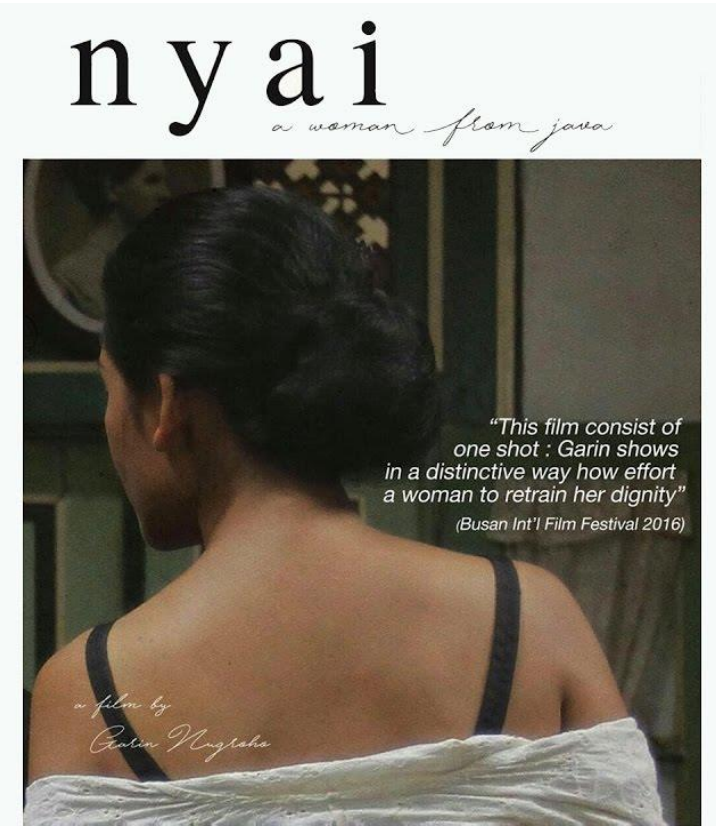

Gambar 1. Poster Film Nyai Karya Garin Nugroho

(Sumber: internet, 2019)
Belanda. Suka duka yang ia hadapi tidak mudah. Ia harus berhadapan dengan masyarakat yang memandang rendah statusnya, ancaman dari ketua serikat dan buruh pabrik, warisan, hingga anak kandung yang dipisahkan darinya karena hukum hak asuh.

Dalam kepedihannya, Nyai mulai belajar bagaimana harus bersikap sebagai seorang istri orang Belanda. Belajar membaca dan menulis, mengikuti perkembangan jaman melalui surat kabar, belajar hukum, dan menjalin hubungan dengan seorang jurnalis. Hingga akhirnya mereka berdua bertemu dan melepaskan hasrat mereka berdua, ditambah lagi selama ini Nyai tidak mencintai suaminya. Selama menjadi gundik, Nyai ditemani oleh dua

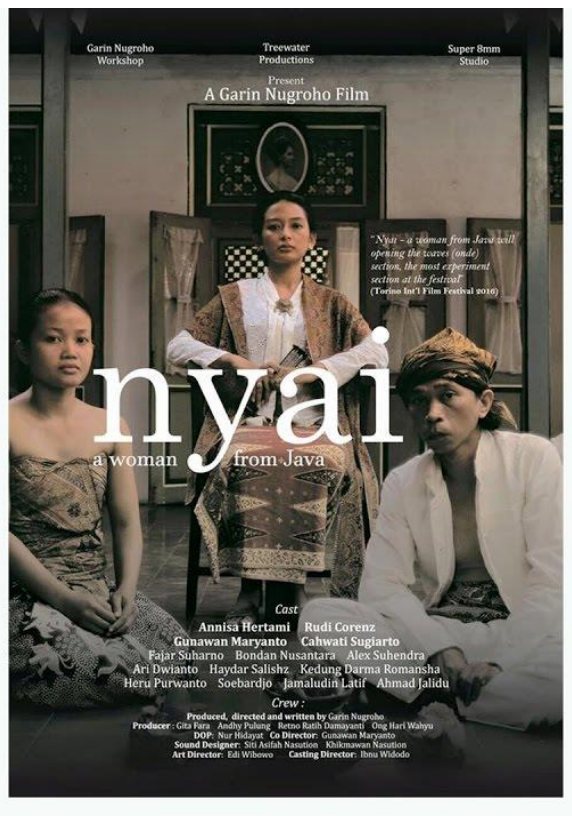

Dari judul film ini dapat ditebak bahwa tokoh utama Nyai adalah seorang perempuan. Nyai (Annisa Hertami) adalah seorang gundik dari Tuan Willem (Rudi Corens), Belanda totok yang memiliki perkebunan dan pabrik. Menjadi gundik bukanlah keinginan Asih (Nyai). Melainkan ia dijual oleh ayahnya sendiri demi kenaikan jabatan Mandor yang dijanjikan oleh orang orang abdi yang setia, simbok dan pembantu laki-laki. Demi memperjuangkan masa depannya, Nyai menggunakan berbagai cara secara hukum. Dalam hubungan rumah tangganya, ia jaga agar dapat menyenangkan suami semaksimal mungkin hingga sang suami dapat sehat selalu dan dapat menjamin hidupnya. 
Meski begitu nasib tidak selalu tenang ketika Nyai mendapati perkebunan dan pabrik Tuan Willem bangkrut, sehingga Nyai kehilangan hak atas harta warisan karena statusnya hanya sebagai gundik. Ternyata Tuan Willem masih memiliki istri yang bernama Liekke dan juga anak yang bernama Hans Van Erk di Belanda. Bahkan Nyai tidak memiliki hak asuh atas anak kandungnya sendiri.

Tokoh Nyai dalam film ini memperlihatkan bahwa perempuan memiliki keterbatasan. Dari situlah Nyai sadar dan belajar bahwa kesadaran itu yang mendorong atas tindakan-tindakannya. Nyai berasal dari keluarga dengan latar belakang tidak berpendidikan yang ditukar dengan uang logam dari tutup kaleng biskuit. Nyai belajar bagaimana mengendalikan dirinya dalam hal politik, seksual, dan juga pemogokan buruh.

Film-film Garin Nugroho kental dengan eksperimentasi. Setidaknya dalam konteks perfilman, Garin Nugroho menjual secara artistik dibanding dalam konteks bisnis. Film-film Garin memang tidak laku di parasan, namun mendapat penghargaan festival-festival di dalam dan luar negeri. Pada film Nyai ini Garin melakukan eksperimentasi dengan menggunakan satu kamera dan dilakukan selama sembilan puluh menit tanpa henti (long take) untuk satu film secara penuh. Long take adalah penggunaan durasi shot lebih dari rata-rata panjang durasi satu shot (Bordwell Thompson, 2008)

Hampir sepanjang film, pengambilan gambar dilakukan secara medium shot dengan posisi kamera hampir statis yang disusun sebagaimana pementasan teater. Konsekuensi dari teknik tersebut menyebabkan Film Nyai seperti pementasan teater di atas panggung. Sirkulasi keluar masuk tiga puluh empat pemain, setting, lighting yang menuntut untuk semua pemain beserta crew hafal dialog dan cue yang tidak dimungkinkan untuk cut to cut. Film ini akan membawa penonton untuk merasakan realita ruang dan waktu yang dulu pernah terjadi, dengan mengikuti alur setiap kejadian, pergerakan pemain dan perpindahan kamera. Dengan visual long take, film mampu memusatkan perhatian penonton karena tidak ada cutting, montage, ataupun hal-hal merusak dan mengganggu perhatian penontonnya.

Dari segi mise en scène semua disajikan senyata mungkin secara teatrikal sesuai dengan apa yang terjadi di atas panggung, seperti pada setting artistik, kostum, properti, penuturan bahasa dan dialog.

Berpijak pada kaidah teknis tersebut dapat dikatakan bahwa film Nyai adalah pertunjukan teater. Seperti pengambilan gambar yang diperhitungkan sehingga sangat sedikit sekali distorsi pada garis-garis pengambilan sudut gambar. Pencahayaan terang merata saat menggunakan penerangan general adalah salah satu ciri khas dari pertunjukan teater dimana penonton dapat melihat segala sisi yang ada di dalam frame. Selain itu terdapat penerangan dengan fokus yang berpindah-pindah dan juga warnawarna pencahayaan yang mendukung alur dramatik.

\section{Penelitian Sebelumnya}

Film yang menggunakan panggung sebagai tempat kejadian (setting) masih jarang ditemukan di Indonesia. Kalaupun ada film-film tersebut hanyalah mengisahkan kehidupan orang-orang teater dengan segala aktivitas kesehariannya, atau mentransformasikan naskah-naskah panggung menjadi sebuah film. Meski demikian penelitian Wibowo pada film Dogville karya sineas Denmark, Lars von Trier, mendapati konsep pemanggungan teater dalam penggarapan filmnya (Wibowo, 2012). Penelitian ini sangat bermanfaat 
untuk pembanding bagi film Nyai karya Garin Nugroho

\section{Landasan Teori}

Secara konvensional, pertunjukan teater terjadi dan menempati ruang di gedung teater. Pertunjukan teater selalu membutuhkan panggung (lihat Carlson \& Shafer, 1990) tetapi kemudian di masa sekarang ini, ada tren tertentu di seluruh dunia untuk menemukan ruang alternatif demi perkembangan teater itu sendiri. Salah satu tindakannya adalah memindahkan tempat pertunjukan dari gedung teater (Sathotho, 2019). Pendapat ini bisa dijadikan acuan untuk melakukan analisis teater terhadap film Nyai karya Garin Nugroho.

Menurut David Bordwell dan Kristin Thompson dalam Film Art menyatakan bahwa mise en scène (Prancis) adalah "menempatkan ke dalam tempat" dan diaplikasikan oleh kerja sutradara. Istilah ini muncul pada awalnya pada konteks pertunjukan panggung dan kemudian juga diaplikasikan dalam film. Mise en scène berupaya untuk mengontrol aspek-aspek film yang berkaitan dengan teater seperti: setting, cahaya, tata rias, kostum, dan gerak aktor. Perencanaan sekenario tidak selalu berjalan sesuai dengan ekspektasi, sutradara dapat merubah perencanaan skenario dan aktor dapat menambahkan garisnya sendiri. Itu semua untuk menunjang efek dramatis pada film. Dengan kata lain, segala sesuatu yang tampak dalam frame adalah kekuasaan sutradara untuk pembuatan film

Mise en scène menurut James Monaco dalam Cara Menghayati Sebuah Film adalah alat-alat yang dipergunakan oleh pembuat film untuk merubah dan menyesuaikan pembacaan syot yang kita lakukan. Karena syot merupakan suatu satuan arti yang besar sekali, barangkali ada gunanya kalau pembicaraan mengenai komponen-komponen kita lakukan dalam dua bagian. Mise en scène adalah segala hal yang terletak di depan kamera yang akan diambil gambarnya dalam sebuah produksi film (Prastita, 2008).

Menurut Cahyaningrum dalam buku Drama Sejarah, Teori dan Penerapannya tentang Mise en scène adalah makna yang muncul karena penerimaan dan rekonstruksi makna oleh penonton. Memaknai Mise en scène merupakan cara meninstreprestasi struktur yang diproduksi oleh elemenelemen artistik pertunjukan (Cahyaningrum, 2012).

Jadi Mise en scène dari segi teater maupun film adalah ungkapan yang digunakan untuk menggambarkan seluruh aspek visual yang ada pada saat memproduksi film atau pertunjukan teater. Seperti setting, properti, aktor, kostum yang digunakan, lighting, dan lain-lain. Semua yang muncul di dalam frame merupakan bagian dari mise en scène yang juga berarti teatrikal atau spektakel.

\section{Metode dan Data}

Penelitian ini adalah deskriptif kualitatif. Penelitian deskriptif kualitatif adalah penelitian yang mengarah pada pendeskripsi secara rinci dan mendalam baik kondisi maupun proses, dan juga hubungan atau saling keterkaitannya mengenai hal-hal pokok yang ditemukan pada sasaran penelitian. Penelitian kualitatif tidak dimaksudkan untuk memberikan penjelasan-penjelasan (explanation), mengontrol gejala-gejala komunikasi, mengemukakan prediksi-prediksi, atau menguji teori apapun, tetapi lebih digunakan untuk mengemukakan gambaran atau pemahaman (understanding) mengenai bagaimana dan mengapa suatu gejala atau realitas komunikasi terjadi dalam masyarakat (Nazir, 1988). 


\section{Hasil dan Pembahasan}

Garin Nugroho tidak secara instan memahami satu bidang seni dalam satu sudut pandang saja. Tiga puluh lima tahun Garin Nugroho berkarya, Nyai menjadi salah satu film yang kontras dari film-film Garin Nugroho sebelumnya. Sebagai film eksperimental, jenis film yang sangat berbeda dengan jenis film lainnya. Para sineas eksperiental umumnya bekerja di luar industri film utama (mainstream) dan bekerja pada studio independen atau perorangan. Strukturnya sangat dipengaruhi oleh insting subyektif sineas seperti gagasan, ide, emosi, serta pengalaman batin mereka (Prastita, 2008).

Sepintas lalu, film-film drama keliatannya dekat sekali pada drama panggung. Tapi film berbeda dari drama panggung dalam banyak hal penting: ia memiliki potensi seni piktorial yang lincah dan cermat; dan ia memiliki kesanggupan bercerita yang jauh lebih besar (Monaco,
Nugroho menciptakan film ini. Film ini seperti layaknya pementasan teater yang dijadikan film oleh Garin Nugroho. Seperti halnya film Nyai yang menjadi film eksperimental Garin Nugroho. Film Nyai memiliki banyak unsur teater atau bisa dikatakan film teaterikal.

Mise en scène berawal dari panggung, kemudian dipinjam istilahnya oleh film. Mise en scène yang dapat juga disebut teatrikal, memiliki lima unsur yang sama dalam Teater dan film yaitu:

\section{Setting dan Properti}

Setting merupakan bagian penting dalam film dan juga pertunjukan teater. Salah satu fungsi setting adalah memberi informasi tentang lokasi dan waktu dalam film. Setting berperan aktif dalam Mise en scène dan menyumbang kepentingan yang sama. Meskipun setting terlihat seperti pendukung cerita semata, namun fungsinya dapat dieksplorasi lebih secara artistik

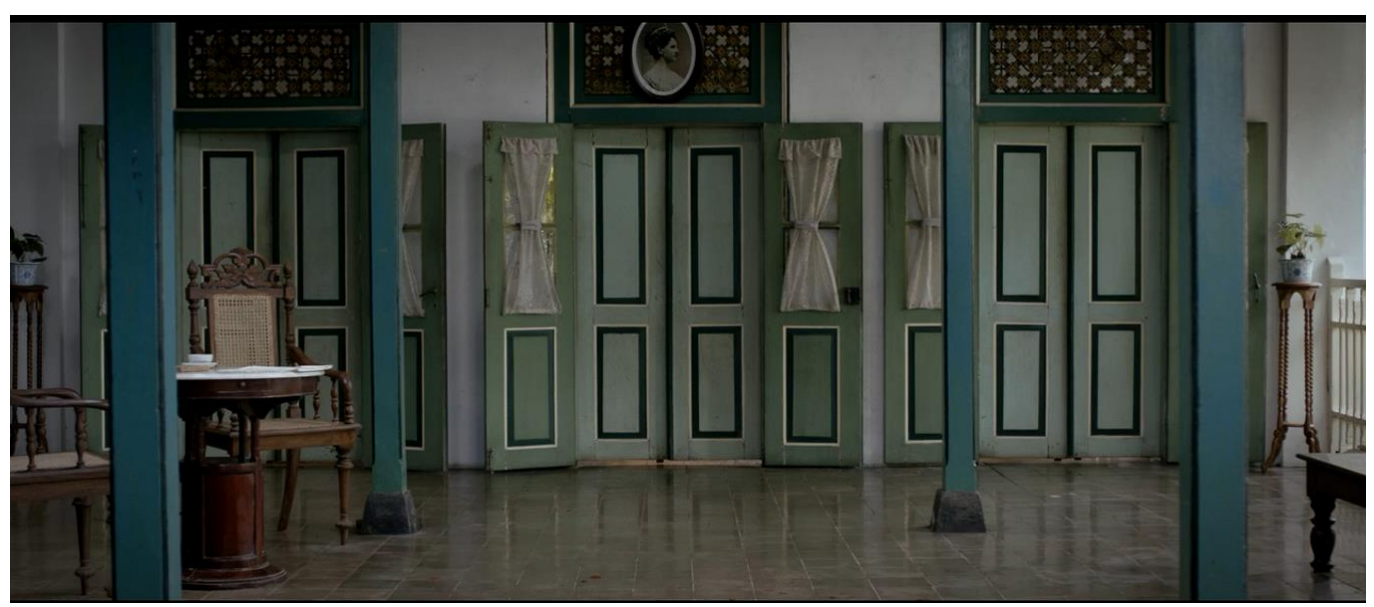

Gambar 2. Omah pendopo yang digunakan untuk film Nyai

(screenshot by Sevin, 2019)

1977). Diangkat dari zaman Indonesia belum bernama Indonesia, film ini berkisah mengenai wanita yang dijual oleh ayahnya demi sebuah jabatan. Wanita itu bernama Asih yang dijuluki Nyai karena telah kawin dengan seorang Belanda.

Dengan tekhnik One shot berdurasi Sembilan puluh menit dan dapat mengatur sirkulasi tiga puluh empat pemain Garin dengan berbagai aspek.Setting (lihat gambar 2) mampu memberi makna pada rangkaian cerita pada film maupun Pertunjukan teater. Bagian dari setting, yaitu properti yang berperan aktif dalam akting si karakter. Memilih, membangun, dan mengatur elemen-elemen setting memberikan kontrol artistik pada sutradara. 


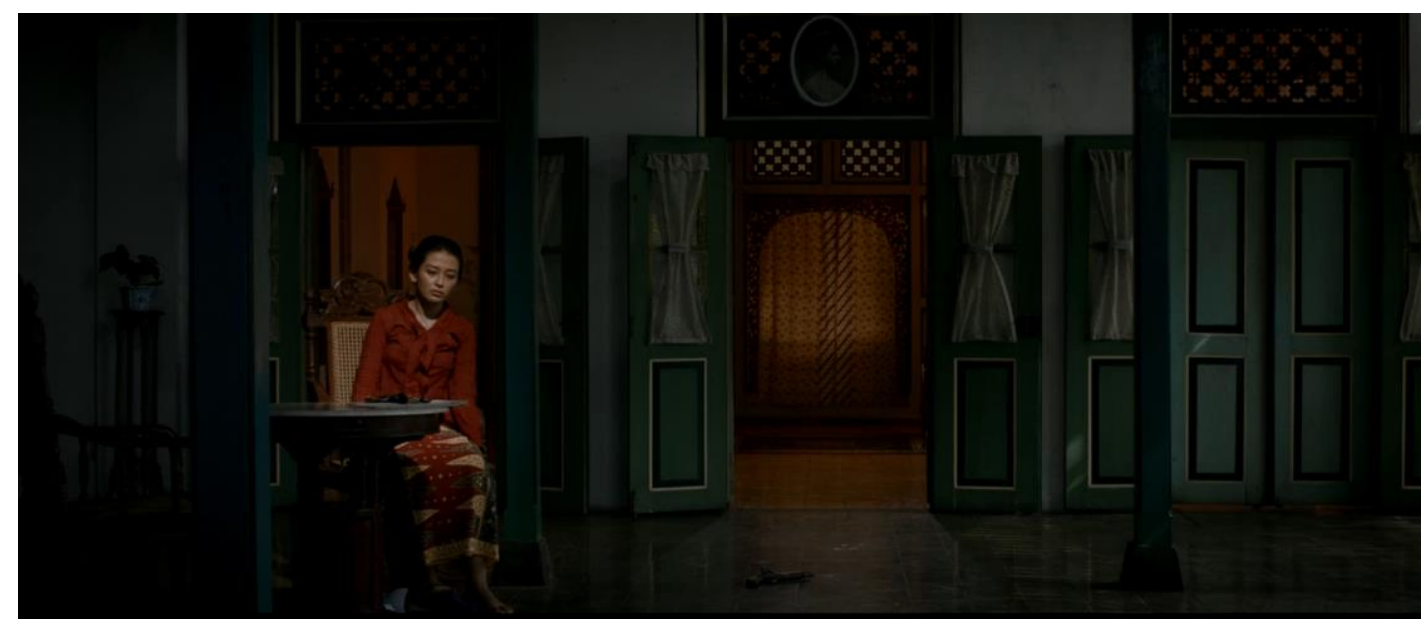

Gambar 3. Cahaya di sekeliling pemeran meredup dan hanya ada satu sorotan cahaya dengan intensitas cahaya yang lebih terang untuk membangun suasana yang lebih dramatis dan juga menonjolkan adegan penting yang dibawakan oleh pemeran.

(screenshot by Sevin, 2019)

\section{Lighting}

Lighting (gambar 3) hadir tidak sekedar untuk menerangi set dan aktor. Lighting dapat menentukan mood (suasana) suatu adegan. Bagi para sutradara, pencahayaan itu lebih dari sekedar penerangan untuk dapat melihat set dan aktor. Pencahayaan digunakan untuk memberi arti lebih tentang seorang karakter atau situasi lewat aksennya. Pencahayaan yang baik dapat dicapai dengan manipulasi dan arah tembak cahaya. Dengan menggunakan pencahayaan dengan kontras tinggi, sutradara bisa menunjukkan dua ruang yang berbeda di adegan tersebut.

Meskipun pencahayaan pertunjukan teater dengan film berbeda intensitas nya secara fungsi memiliki tujuan yang sama, seperti membangun suasana, penerangan set, aktor, dan juga penanda.

\section{Make-Up dan Kostum}

Setiap pemain biasanya menggunakan pakaian dan make-up yang khas untuk memperkuat karakteristik. Sehingga perlu dipertimbangkan dengan matang pemilihan model pakaian dan warna

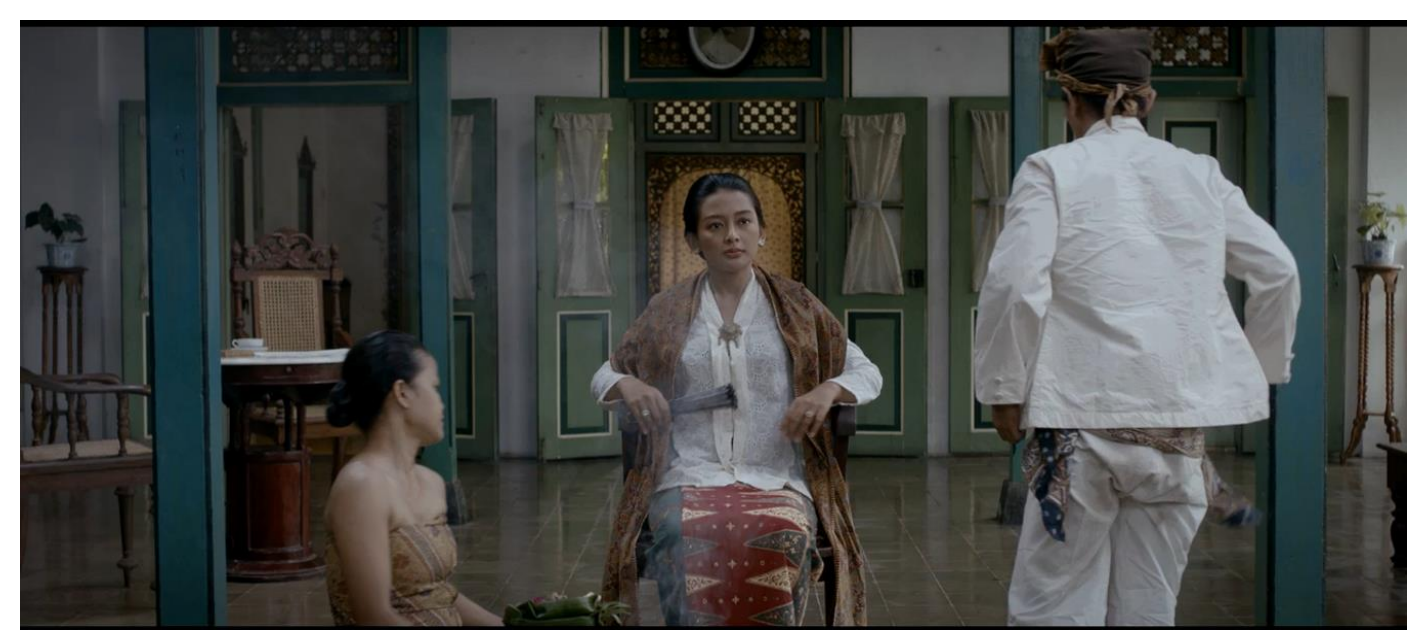

Gambar 4. Film Nyai Karya Garin Nugroho pada setiap adegan para pemeran memiliki unsur warna putih dan coklat pada setiap kostum yang dikenakan (screenshot by Sevin, 2019) 
yang digunakan. Karena warna mampu menggambarkan psikologi karakter tersebut.

Selain mencerminkan karakter, pemilihan make up dan kostum dapat menjadi simbol terhadap sebuah zaman, negara, budaya, atau status sosial tokoh. Pemilihan tergantung setting yang sudah ditentukan pada pembahasan tentang setting sebelumnya (gambar 4). menentukan tingkat ketebalan make-up, corak serta warna kostum. Sedangkan film tergantung dari bagaimana angle yang digunakan saat shot untuk menentukan ketebalan make-up, corak serta warna kostum.

\section{Blocking}

Blocking (gambar 5 dan 6) adalah pengelompokan pemain pada saat di atas

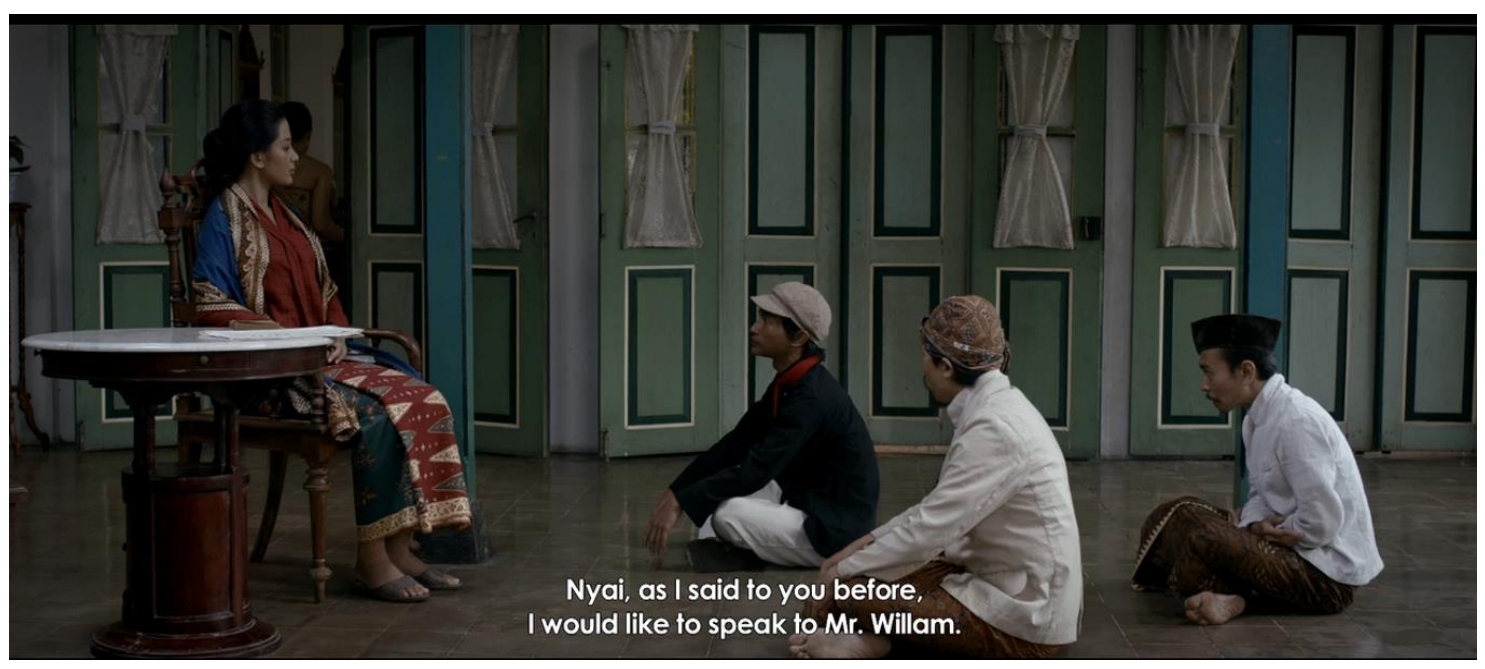

Gambar 5. Adegan Nyai kedatangan kepala buruh dan juga kepala kabupaten satu dan dua. (screenshot by Sevin, 2019)

Secara teknis make-up dan kostum untuk pertunjukan teater dan film jelas berbeda. Dipengaruhi dari jarak pandang. Pertunjukan teater mengandalkan lokasi atau tempat pertunjukan itu sendiri untuk panggung, blocking tersebut harus seimbang, utuh, bervariasi dan memiliki titik pusat perhatian. Teknik ini menjadi tolok ukur seorang pemain dalam pementasan seni teater. Berbeda halnya dengan pengertian

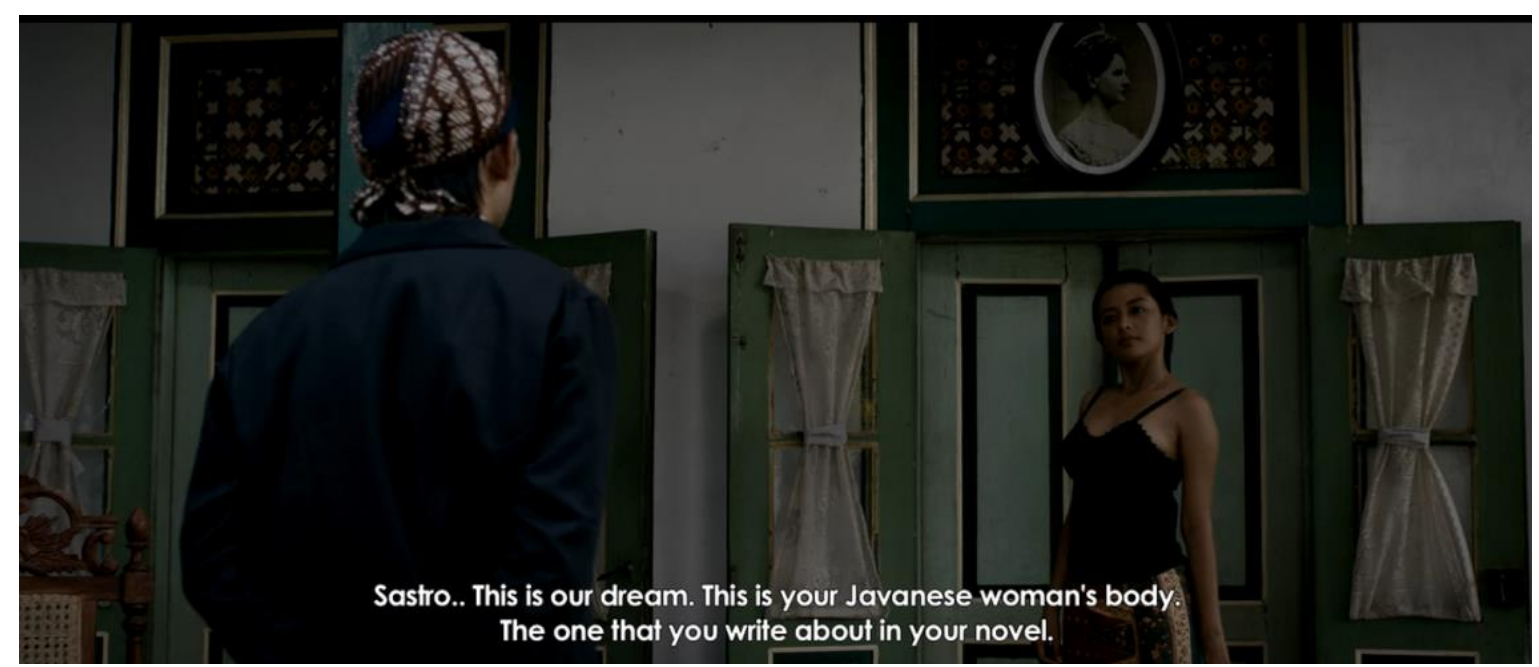

Gambar 6. Adegan Nyai menggoda seorang Jurnalis. Bernuansa romantis dan bermakna sendu. Nyai menempati bagian belakang tengah panggung (BT) (screenshot by Sevin, 2019) 


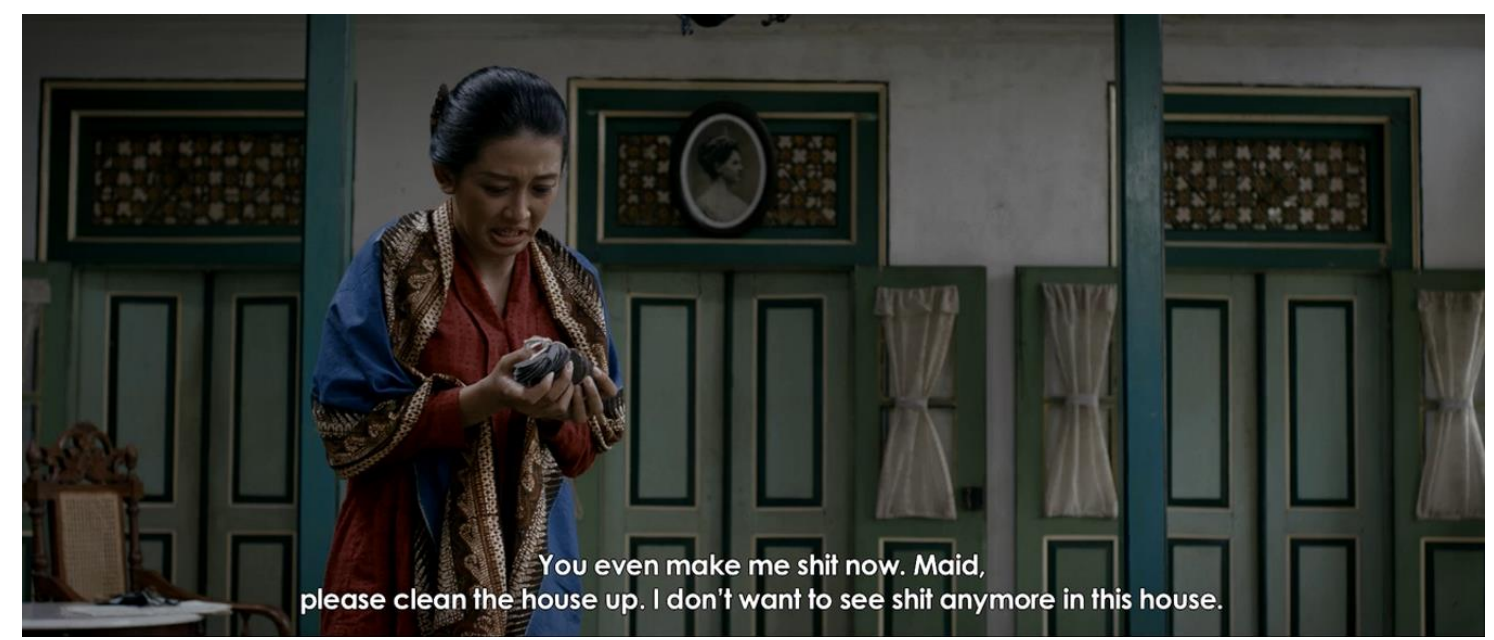

Gambar 7. Di saat seorang pemeran sendiri, ia memiliki jarak terhadap barang-barang di sekelilingnya dan membuat komposisi panggung menjadi lebih indah

(screenshot by Sevin, 2019)

blocking pada film. Biasanya blocking pemain sudah dirancang saat membuat storyboard, tergantung bagaimana permintaan sutradara atau Director of Photography.

\section{Akting}

Akting untuk aktor film dan aktor teater juga dibedakan melalui jarak pandang penonton dalam setiap lokasi pertunjukan teater karena pertunjukan teater bersifat pertunjukan langsung. Sedangkan film tergantung angle kamera. Hal yang terpenting adalah bagaimana seorang aktor mendalami perannya dan dapat menerapkannya seolah-olah ia dapat melihat bentuk tubuhnya sendiri saat memerankannya (gambar 7).

Unsur teatrikal dalam teater dan film sama-sama dimiliki dengan kebutuhan yang berbeda, penerapan yang berbeda karena media yang berbeda. Namun bukan menjadi suatu masalah jika teater dan film dikolaborasikan. Perlu perhitungan yang matang dalam penerapannya.

\section{Simpulan}

Film Nyai karya Garin Nugroho merupakan paduan bentuk antara teater dan film. Film Nyai muncul sebagai film dengan berbagai idiom teater di dalamnya. Hal tersebut menghasilkan kesan seperti menonton pertunjukan teater di atas panggung saat menikmati pemutaran film Nyai di dalam gedung film.

Menganalisis film Nyai dengan pendekatan teori teater adalah langkah yang tepat. Sudut pandang yang digunakan untuk membuktikan adanya idiom-idiom teater menggunakan pemahaman terhadap Mise en scène dalam mengkaji unsur teatrikal pada film Nyai.

\section{Daftar Pustaka}

Bordwell. David dan Kristin Thompson, Film Art, Mc-Graw Hill Companies, New York, 2008, hlm.208

Cahyaningrum. Dewojati,. Drama Sejarah, Teori, dan Penerapannya, Penerbit Javakarsa Media,Yogyakarta, 2012

Carlson, M. \& Shafer, Y. (1990). The Play's The Thing: an Introduction to Theatre. New York: Longman JPNN.COM, Film Nyai Karya Garin Tidak Beredar di Bioskop Tanah Air, 2018, https://www.msn.com/idid/hiburan/film/film-nyai-karya-garintidak-beredar-di-bioskop-tanah-air/arBBO9c8E (diakses pada 14Januari 2020) 
Monaco, James. Cara Menghayati Sebuah Film, Yayasan Citra, Jakarta, 1977

Nazir, Moh. Metode Penelitian, Jakarta : Ghalia Indonesia, 1988.

Prastita, Himawan. Memahami Film, Homerian Pustaka, Yogyakarta, 2008

Riantrisnanto, Ruly.Sorot Pernikahan Era Kolonial, Film Nyai Diangkat dari 5 Novel Legendaris 2018, https://www.liputan6.com/showbiz/rea d/3663256/sorot-pernikahan-era-

kolonial-film-nyai-diangkat-dari-5-

novel-legendaris (diakses pada 13 Januari 2020)

Sathotho, Surya Farid. Membangun Ruang Urban Alternatif Melalui Performance Art, Tonil, vol 16 no 1 (1-5)

Wibowo, Philipus Nugroho Hari. Konsep Teater Epik Brecht dalam Film Dogville dalam Journal of Urban Society's Arts vol.12 no.2, Institut Seni Indonesia Yogyakarta, Yogyakarta, 2012, hal.55-54

Video

Film Nyai (2016) Karya Garin Nugroho 